\title{
The Role of Social Learning in Rural Development
}

\author{
Katalin Liptak $^{1 *}$, Klara Szucsne Markovics² \\ ${ }^{1}$ University of Miskolc, Institute of World and Regional Economics, Hungary \\ ${ }^{2}$ University of Miskolc, Institute of Business Sciences, Hungary \\ *Corresponding author
}

\begin{abstract}
The aim of the study is to examine and present social innovations that have been successful in the North Hungary and South Transdanubia regions, and that have improved the employment and competitiveness positions of the region or the given municipality. The two regions have similar economic and social features and a similar spatial structure of small villages, yet we will see that the issue of social innovation is nevertheless completely different in the two. In the Northern Hungary region, two less known innovations were chosen: the activities and social innovation of the Self-Reliant Otherness Quality of Life Development Foundation, and the production of pumpkin seed oil in Boldva. In the South Transdanubia region, I characterize the community employment based on the Belecska social land programme and the "Fate-transforming - Destiny-shaping" programme in Gyulaj, which are much better known social innovations that have been operating for decades, although their adaptation and transposition to other regions is for the most part unsuccessful. Thus, I considered it worthwhile to explore the essence of these programmes, the process of social learning, which can help transfer the successful elements into the practice of other municipalities.
\end{abstract}

Keywords: countryside, social innovation, social learning process

\section{Introduction}

Some of the social innovations are closely linked to rural development, as local economy development or local solutions to improve employment are increasingly important given the specific social and economic processes in rural areas. The social innovation provides a new and novel solution to the existing social problems (Veresné Somosi \& Varga, 2021; Bozsik et al., 2021; Karajz, 2021; Szucsne Markovics, 2021; Veresné Somosi \& Balaton, 2020; Bozsik et al., 2020; Musinszki, 2019; Bozsik et al., 2019; Hajdú et al., 2019; Szucsne Markovics, 2015).

Both the concept of countryside and the countryside itself have undergone a significant transformation in Hungary in recent decades. Just as there are many different approaches to the concept of countryside, there are also different approaches to the concept of rural development. According to Kulcsár (2017), the concept of rural development seems to be both too broad, elusive and too narrow, because on the one hand, every planned change in the countryside is considered as rural development, and on the other hand, it can apply to the whole country due to the ambiguity of the concept behind the term "countryside". I agree 
with Kulcsár (2017) that rural development is development based on endogenous resources, and that rural development is complex in nature and can involve several disciplines. According to Vincze (2013), rural development refers to the self-sustainable and sustainable development of the capacities in rural areas. Endogenous rural development relies on local natural and social resources as well as local culture or identity. Due to the specific developmental characteristics of peripheral and rural areas, the emergence and course of innovations are different from those in the centre. Due to the composition of society in a peripheral area, to its different use of space and its attitude to culture and customs, different methods are required in rural areas than in urban ones.

Good practices abroad and in Hungary show that there is no single recipe for innovation in rural and peripheral areas, that every successful solution is unique; that new products and processes are not created in scientific workshops but in practice, right on the spot; and that social innovations are at least as important as technical and technological innovations. Policymakers see the solution to rural problems in the context of innovative development based on local resources, which may be considered as social innovation. The aim of this study is to examine the concept and characteristics of social learning that facilitates the emergence of social innovation, as Hungarian authors (Nemes \& Varga, 2017; Kozma, 2011) see social learning as the key to the spread of social innovation. To this end, I will describe two successful social innovations in two different regions.

\section{Social innovations in Northern Hungary}

In Hungary, I have identified a number of social innovations. The best known are the work done by the Szimbiózis Foundation in the employment of people with disabilities in the Northern Hungary region and the innovative public employment programme in Hernádszentandrás. In this study, I will present the work of another foundation, the SelfReliant Otherness Quality of Life Development Foundation (hereinafter: ÖMÉFA), which, similarly to the Szimbiózis Foundation, employs people with disabilities, but is less well known.

ÖMÉFA is a civil society public benefit organisation based in Miskolc, founded in 2006 with the aim of running a social day-care centre and providing developmental services to people with disabilities to enable them to work in the open labour market. Between 2009 and 31 March 2017, its workshops were run as a social institutional employment service, but due to a change in legislation, currently hey are correctly described as a development employment service. The day-care centre employs 12 people, a manager, three therapists, including a professional manager, and other social workers and carers. The organisation also plays the role of a recruitment agency, and has been doing so for 10 years, with the co-operation of around 600 companies throughout Borsod-Abaúj-Zemplén County. The service runs agency offices in Kazincbarcika, Szerencs, and Miskolc. A major incentive for companies to employ people with a disability is the statutory rehabilitation contribution, which is paid by employers if they employ more than 25 people and the ratio of people with a disability they employ is less than 5\%. They are typically approached by larger companies. Unfortunately, due to a shortage of human resources and since the head of the institution works at full capacity, there is no time or energy to promote the organisation. ÖMÉFA is presented at the 
Martin János Vocational School at parents' meetings, but the best way for potential employees to reach the organisation is through referrals between parents and through acquaintances. They do have a website, but they are not active on the internet. As another disadvantage is the narrow range of jobs available for employment. This should certainly be widened, for example, carpenters and dry pasta makers, etc. could be added. A risk factor is that employment projects have variable and unpredictable subsidies available from year to year, with applications having to be made every year. As the foundation is essentially grantfunded, this creates a surge in employment. As they perform a public task, the state budget is available, but it can only be used for the maintenance of the institute. Unfortunately, since 2006 the grant has remained unchanged at HUF 500,000 per person per year for civil society organisations, which is used to pay the salaries of the staff and utility charges.

ÖMÉFA runs 5 workshops within the day-care centre. In the sewing shop puppets and tablecloths are made, the weaving shop produces textile-based objects, the paper shop makes picture frames and postcards of millboard, and in the ceramics workshops ceramic ornaments and household utensils are made using different techniques. The items made in the workshops are unique and are made for sale, for fairs, village festivities or other similar events, or for parents to buy, and they also work to order. The proceeds are reinvested in employment, used for purchasing raw materials for making additional products. Their day-care facility is licensed to accommodate 80 people. Their employees come from Borsod-Abaúj-Zemplén County, mainly from the districts of Miskolc, Tiszaújváros, Kazincbarcika and Edelény, and have been employed for two years. The total employee headcount is 70 .

In the framework of the developmental employment service, 16 young people with disabilities work in the institution for 4-6 hours a day. If the foundation has an employment contract with the employee, the latter receive a wage, while under a development contract; they receive an hourly rate as grant in aid. The organisation is also an accredited institution, which allows for the employment of people with disabilities, with 22 such workers currently employed. Asked about feedback (impact) on the outcome of their activities, the manager first answered by a question: "How can this impact be measured? Actually, we can measure it by the length of time spent by such a person in employment." Their placement service is able to place 60-80 people per year. We also asked them about the success of the programmes and the possibilities for monitoring and feedback. A 6-month follow-up is customary in the labour market service. After they have successfully mediated someone to a company, they call the employee and ask him or her about the employment. The manager of the foundation said that based on feedback the companies are satisfied with the employees they place in companies, and that employing people with disabilities was seen an important task for the labour market. The other example is the village Boldva in Borsod-Abaúj-Zemplén County, where coldpressed pumpkin seed oil is produced and sold with the help of public employees. Nowadays, local products are increasingly in demand all over the country, because with the unfolding of a countertrend to globalisation consumers are making efforts at more conscious purchasing and are looking for products and food that are made or come from in the country or perhaps in their region. Buying these products not only reflects consumer awareness, but can also lead to a boost in the Hungarian economy. In an even narrower perspective, for numerous microregions and municipalities, one of the chances of getting involved in the economy is through local products. At the same time, local products also play a role in the development of the 
particular area, because in order to produce something, the raw material has to be produced, the product has to be manufactured and sold, and all these demands create employment (Burka \& G. Fekete, 2017).

Pumpkin seed oil is the primary product of the Boldva oil plant, which was established to produce it. Public employment is a state-subsidised form of employment aimed at increasing the number of jobs and thus reducing unemployment. In Boldva, this is done through the Start Public Works Programme, including farming, growing herbs, oil pumpkin and other agricultural products. It also follows that the logic behind the plant is to provide work for as many people as possible by growing and harvesting the pumpkin, pressing the seeds and packaging the oil. By growing pumpkin on their own land using semi-mechanised methods, they contribute greatly to the small-scale exploitation of local resources, while they also minimise transport costs in the "raw material sourcing" process. Waste generation is also lower due to the recovery and sale of by-products. A properly maintained factory environment is emerging, with a previously unused, derelict building being renovated for the plant. The plant, run by the local government of Boldva, selected local entrepreneurs as its prospective partners. As pumpkin seed oil has been pressed for only a few years, operation is still in its early stages. The result is employment as a favourable economic impact, however, it remains less significant due to the small number of employees. The revenues from the sales go to the local government of Boldva and are reinvested in the plant. Over the long term, the objective is self-sustainability.

\section{Some social innovations in Southern Transdanubia}

The Southern Transdanubia region (Baranya, Somogy and Tolna counties) is relatively abundant in social innovation. The spatial structure of the region is very similar to the Northern Hungary region, with a relatively high number of small villages with almost no job opportunities available, high unemployment, low social potential, low skilled human resources and low regional income characterise the LHH district of Tamási, which is a region of cumulative disadvantage. Here is an overview of the best-known social innovations for the improvement of the local economy and employment.

Belecska is a village of 365 inhabitants in the Tamási District of Tolna County. The municipality has 1479 hectares of land, of which 57 hectares are located within the municipal boundaries of various localities. $70 \%$ of the periphery is covered by forest. The quality of agricultural land is poor, with low values (bw. 12-17 gold crowns per hectare). Classic agriculture is practised; mainly maize and cereals are grown. Livestock numbers have fallen significantly. There is a high ratio of elderly people in the village, and social meals are offered and a social home-care service is provided. There is a kindergarten in the settlement, but no primary school (Petrovicsné, 2006).

After the change of regime, when the producers' co-operative was dissolved, people in the village became unemployed, and the mayor wanted to make sure that families with young children had job opportunities in the area, as he feared mass emigration. Similarly to other cases, the mayor has a key role in this social innovation, as he had the idea and looked after the interests of the community. An employment programme based on fruit and vegetable production has been running in purely public interest for more than fifteen years. Vegetable 
and fruit growing was started in the late 1990's under a social land programme with subsidies. Initially strawberry was grown. The strawberries were already profitable in the first year, which made it clear that there could be a future for fruit and vegetable production in Belecska. This led to a steady expansion of the programme, which has continued unabated ever since. At present, production takes place on 25 hectares: the municipality's own land is involved, while long-term leases are also used. Monoculture farming, which was briefly based on strawberries alone, quickly expanded to include a wide range of vegetables, fruits and vines, and plans are underway to plant and grow more (Németh, 2011).

The scheme in Belecska is referred to in the press and in common parlance as a social land programme, rather than a farm work programme in the traditional sense. The essence of classical social farm work programmes is that they create opportunities for small-scale backyard production and animal husbandry by providing discounted services and benefits to socially disadvantaged people who do not have the necessary assets for agricultural production, or who cannot run it efficiently, by using individual and community and local resources (Jász et al., 2003:139). The Belecska programme is based on foundations that differ from this concept. By performing production and sales in the framework of a non-profit enterprise, the village government created a unique local employment solution that is inseparable from the land, but is not a farm work programme. The Belecska scheme is more appropriately called a social employment (social economy, community-based economy, or village economy) programme based on the municipality's enterprise (Németh, 2011).

Due to administrative problems and VAT regulations, in 2002 the Priority Public Benefit Company Operating the Village Belecska was established by the local government as the sole owner to run the programme, which was then transformed into a non-profit limited liability enterprise on 1 July 2009.

The programme continues to provide jobs for local people, initially providing part-time employment for 4 people, but in 2010 it already provided a living wage for 23 full-time workers. Belecska is essentially self-sufficient in fruit and vegetables and also produces for the regional market. As a result of the programme, the initial $30 \%$ unemployment rate has fallen to a negligible level. The programme has significantly alleviated insecurity, and a very important indirect result is that children are being born again in the village, the population decline has stopped; the population is essentially stagnating, and in some years even slightly increasing. As a result of the programme, social assistance has been eliminated, unemployment in the village has virtually been eradicated, and moreover, all this was achieved through community farming.

The case of Belecska is instructive, because most social innovations are not only successful in themselves, but there are already good examples of their adaptation. The practice of transposing social innovations to other regions is very important in order to apply good practice. We can see that even in the Tamási District, in villages like Belecska, the adoption of this social innovation that seems to be relatively simple has been unsuccessful. The spontaneous adaptation of the Belecska programme may be hampered by the adoption of at least some of the essential elements of the programme. This means that the example of Belecska is not as clear for the other communities as it could be, despite the fact that the mayor has presented the key elements of community farming on several social forums, and yet, familiarity with the concept has proven to be insufficient alone. Something else is needed 
for adaptation, and this is the pursuit of self-sustainability, which has been successfully achieved in Belecska. Another specific feature of the adaptation is that the municipality of Belecska has its own arable land in the precincts of the village. Other settlements with similar economic and social characteristics in the Tamási District do not have land in their ownership in the outskirts of the locality, nor the capital to buy or rent land.

According to Németh (2011), there is nothing specific to Belecska behind the results achieved by the village economy programme, i.e. there are no local factors or resources whose difficult and expensive adoption or reproduction would prevent other villages from trying to find solutions to their employment problems in this way, but there is a reluctance among local government leaders in small municipalities in Hungary to set up a business and start one. In this light, adaptation can only be successful where local leaders are capable of adopting an entrepreneurial approach. In this respect, the Belecska programme is indisputably person-dependent. It is important for the municipality to become a local development hub through intensive tendering and continuous innovation channelling.

Gyulaj is a village of 980 inhabitants in Tolna County, which is in a difficult situation, In the 1960's Boyash Roma were also resettled here. The mayor's vision was in line with the "Fatetransforming - Destiny-shaping" programme in 2009. At that time, the Fate Transforming Labour Market Programme, organised by the Labour Centre, had already been well underway, providing training and a year's paid employment for the long-term unemployed with the involvement of local authorities. Part of the programme was specifically aimed at getting local governments to start growing produce on their own land, providing jobs for their residents and relieving the burden on their public kitchens. The programme started in 2010, with 10 people enrolled in the first round. More land was brought under cultivation from the autumn of 2010. The long-term goal is for the local government to be able to provide $100 \%$ of the basic vegetables for the public kitchen. Previously grown vegetables (mainly potatoes) are now cultivated on a considerably larger area, and new crops have been introduced: strawberries, lettuce and garlic have been planted.

A new opportunity arose at the end of the first year, when production expanded beyond vegetable crops to include some herbs and medicinal plants. The local government was approached by a herb processing enterprise, which was contracted to grow marigold, lavender and hoary willow herb. Already in the first year, the sale of marigolds generated nearly HUF 40 thousand in revenue for the local government. The local government takes the plans based on the herbs so seriously that they have had workers make drying trays for the eventual subsequent processing of larger quantities. At the same time, the range of herbs grown has also expanded, as it provides more or less guaranteed income to the local government, and this may help the programme to become self-sustaining (Németh, 2011).

In an effort to also expand the profile of the primary school, the 9th and 10th grade agricultural vocational class was launched in 2011. Students learn gardening on their shared land, just as their parents, relatives and neighbours do similar work on larger municipal plots. The municipality would like to involve the residents of Gyulaj in the programme as much as possible in the future. On the one hand, if funds can be obtained from the social land programme, they would also like to provide the population with free seeds and seedlings for gardening to help households become self-sufficient. They would also like to involve as 
many residents as possible in the cultivation of certain types of herbs and medicinal plants, if the opportunity arises.

This is a form of public employment where value is created, as the workers perform this agricultural activity aware of its benefits for them.

\section{Social learning or social learning - conceptual clarification}

The successful social innovations described above are good examples of the fact that familiarity with the social learning process is required for the transposition of this practice in other regions. "Valid knowledge rests on the consensus of the theory of truth, with the actors continuously exploring the new, leaving behind the old, and relying on the inquiry into the facts. [...] Democracy must begin at home, and its home is the neighbourly community" John Dewey's words are quoted by Vercseg (2013). I believe that Dewey's ideas also apply to social learning.

From a pedagogical point of view, learning is the most important formative activity used in the educational process for the development of students. Human learning may take four basic forms: such as verbal, sensory, motor and social learning (Fodor, 2008). The wider dissemination of the theory of social learning, which is also closely linked to social innovation, was hallmarked by the name of Albert Bandura in the late 1970's. The concept has undergone significant changes in the decades since then, and there are still several parallel approaches. Through social learning, we learn rules of behaviour, habits or social behaviours from careful observation of others. It is a specific form of human learning (observational or model-following) that takes place in a social context (Fodor, 2008).

The theory of social learning, however, was developed by Bandura and Walkers (1963), who approached the essence and most important features of social learning from the perspective of personality development. Albert Bandura's social and cognitive theory explains behaviour in terms of mutual determination, i.e. human functioning is shaped by the interaction of personal factors, behaviour and environmental factors. Not only are we influenced by our environment, we can also shape our environment, but our cognitive processes determine how we react to environmental events, what events we perceive, how we interpret them and how we respond to them (Bandura, 1989). According to Bandura's theory, the acquisition of the necessary behavioural patterns is a complex learning process regulated by cognitive processes (Horváth, 2004).

Bandura placed the role of socialisation in the development of personality on a new footing, which is a basic concept in the sociology of education. He described learning from the social environment as model following and distinguished three forms: verbal, observational and symbolic (Kozma, 1999). After Bandura's work, this social psychological approach to social learning is called "social learning".

Bandura's (1977) research with children formed the basis for the further development of the social learning model. He studied the development of aggressive behaviours in children, based on the idea that important social behaviours and the vast majority of behavioural norms are acquired through the observation and imitation of others. The effectiveness and quality of imitative learning, according to Bandura (1977), is based on four criteria:

- attention, 
- memory,

- production,

- motivation confirmation.

Many people identify social learning as a social psychological concept and simply call it social learning, but there is another, broader understanding of social learning that links the socialisation of the individual to the transformation of the community. According to Horváth (2004), social learning is the acquisition of skills, knowledge and behaviours that enable integration into and thus effective functioning in a group. The main forms of social learning include:

- Direct education: direct instructions, also known as linguistic interventions, because they give specific instructions about behaviour.

- Shaping: behaviour is shaped by reinforcements; rewards and punishments are used to make desirable behaviour appear or not appear.

- Modelling: reinforcing or punishing the behaviour of the model has a strong impact on the imitation of the behaviour. (Solymosi, 2004).

\section{The role of social learning in the evolution of social innovation}

According to Reed et al. (2010), social learning is often confused with the conditions and methods that can facilitate, assist and provide a supportive environment for it. Social learning is the process of change in understanding and problem-solving that goes beyond the individual, as the process takes place at the social level, in some kind of "community of practice", through social interactions (Reed et al., 2010). This definition emphatically separates social learning from the development of the individual, identifying interactions in society as the main method of learning, resulting in some level of change in society (Nemes \& Varga, 2017).

Social learning is therefore a social consensus of people living in community in a given area, in a local society, integrating new information, coming up with their own solutions to problems, discussing the future of their community, developing scenarios and agreeing on goals (Kozma et al, 2011). Social learning is frequently associated with lifelong learning, but it is important to recognise that there is a substantial difference between the two, as lifelong learning is about increasing individual knowledge.

Social learning can also be understood as a process by which a community becomes capable of some action or activity that it was not capable of before. According to Nemes (2018), social learning requires expansion of the following knowledge:

- Cognitive / scientific / technological knowledge / capacity: "theoretical" knowledge that can be learnt and transferred at school, from books, publications, and experts.

- Practical, hands-on knowledge / capacity: skills and abilities that are acquired through practice.

- Situational knowledge/capacity: knowledge related to social relationships and networks, which refers to the existing network of relationships and social networks.

However, Nemes (2018) argues that social learning is not the prerogative of grassroots communities, rather it is needed at all levels. The central, political sub-system of rural 
development is made up mainly of interdependent institutions operating at different levels and in different functions, and one of their main tasks, according to the current orientation of rural development policy, is to support social innovation. In a well-functioning multi-level governance system, social learning takes place in a complementary and balanced way at different levels, with continuous monitoring and matching of knowledge gaps and needs.

According to the basic approach of Bandura (1977) presented above, four aspects are important in the imitative version of social learning. These four aspects are also necessary for social innovation. I have developed a theoretical process model based on Bandura's imitation learning (Figure 1). For social innovations, it is a prerequisite that a successful innovation already operating in one region can be transferred and adapted to another region. Hence, attention also applies in this case: as we study and investigate successful social innovations through observations, the second step is memory (according to Bandura), which applies when adapting social innovations by memorising the key success factors and good practices. The penultimate phase is production, which may be interpreted as an innovation already functioning, and finally the reinforcement of motivation, which can help and support implementers to work effectively.

Figure 1: The social learning process for adapting social innovation
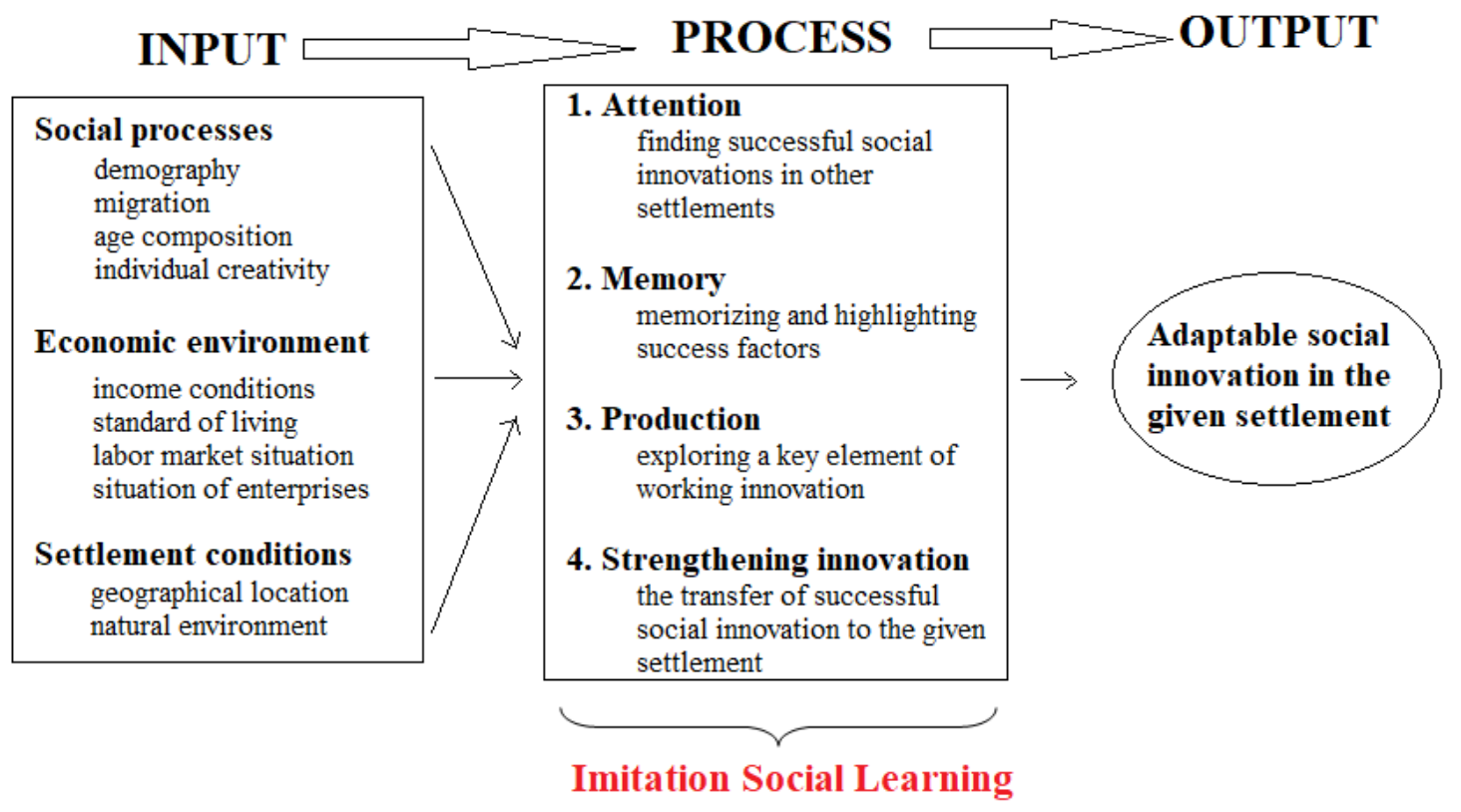

Source: Author's own elaboration

Successful change requires group members to experience for themselves what it is like to be a "subject in action" and to collectively make an impact on their environment. I believe that for social innovations, it is crucial that the initiative and the idea emerge locally and involve local resources, as these are important factors in local development and rural development theory. 
Many also interpret the concept of a "learning region" as a result of social learning, since learning regions combine the level of urbanisation with lifelong learning in the process of learning. In learning regions, accelerated urbanisation processes can be explained by the spread of innovation and creativity. A learning region and a learning municipality is a local society in transition and renewal, where the willingness and readiness of the actors to innovate, the inclusiveness, openness and creativity of the community are important.

\section{Conclusion}

It is clear that social innovation and social learning are inseparable concepts, one serving the other and vice versa. Social innovations driven by social learning can be considered as the basis for rural development, at lower levels only successful local developments with high employment potential. The social learning process can facilitate the conscious transposition of a successful innovation from one region to another. The basic assumption is that social innovations can be replicated if the success factors and key drivers are carefully studied and built upon. Social innovation requires a strong local network of interrelationships and an innovator (or "local hero") with links beyond the immediate environment to back up the ideas. If adopted relatively quickly, the innovation will spread quickly and have a lasting impact. The basis for a sustainable, good relationship is that the innovator must have certain necessary innovation skills. This includes being open to new ideas, creativity and initiative. As these qualities are not always combined in a single person, the innovator may be a group.

\section{Acknowledgment}

This research was supported by the EFOP-3.6.2-16-2017-00007 project entitled Aspects of the Development of a Smart, Sustainable and Inclusive Society: Social, Technological and Innovative Networks in Employment and in Digital Economy. The project has been supported by the European Union, and co-financed by the European Social Fund and the Government of Hungary.

\section{References}

Bandura, A. (1976): Szociális tanulás utánzás útján. In: Pataki F. (Ed.): Pedagógiai szociálpszichológia. Gondolat Kiadó, Hungary: Budapest, pp. 84-123.

Bandura, A. (1977): Social learning theory. Prentice Hall, Englewood Cliffs: New Jersey.

Bandura, A. (1999): Social cognitive theory: An agentic perspective. Asian Journal of Social Psychology, vol 2. pp. 21-41.

Bandura, A. and Walkers, R. H. (1963): Social learning and personality development. Holt, Rinehart and Winston: New York.

Bozsik S., Musinszki Z. and Szemán J. (2019): A Central European approach to the typology of social enterprises. In: Nemec, R., Chytilova, L. (Ed.): Proceedings of the 13th International Conference on Strategic Management and its Support by Information Systems 
2019 (SMSIS 2019), Ostrava, Czech Republic: VSB-Technical University of Ostrava, pp. 25-32.

Bozsik S., Szemán J. and Musinszki Z. (2020): The Role of Human Resource Management Indicators in Social Enterprises with Special Regard to the Social-Cooperatives; European Journal of Social Sciences, vol. 3 (2), pp. 60-75.

Bozsik, S., Szemán, J. and Musinszki, Z. (2021): Management Problems of Social Cooperatives in Hungary Based on a Questionnaire Survey. In: Musinszki, Z., Horváthné Csolák, E., Szendi, D., Szücsné Markovics, K. (Eds.): The impacts of digitalization, social innovations and conflicts, University of Miskolc, Faculty of Economics, Hungary: Miskolc, pp. 27-47.

Burka, N. and G. Fekete, É. (2017): A hidegen sajtolt tökmagolaj, mint helyi termék szerepe a helyi fejlödési folyamatokban, In: Lipták K. (Ed.): Társadalmi innováció és felelősségvállalás Észak-Magyarországon, Miskolci Egyetem, Gazdaságtudományi Kar, Hungary: Miskolc, pp. 43-54.

Fodor, L. (2008): A szociális tanulás jelentösége a pedagógiai folyamatban [Online], Available: http://rmpsz.ro/uploaded/tiny/files/magiszter/2008/tavasz/03.pdf

Hajdú, N., Lipták, K. and Musinszki, Z. (2019): Probléma alapú tanulás a közgazdász képzésen,

In: Tóth, P., Horváth, K., Maior, E., Bartal, M., Duchon, J (Eds.): Neveléstudományi kutatások a Kárpát-medencei oktatási térben: Pedagogical Research in the Carpathian Basin Educational Space, Selye János Egyetem Tanárképző Kar, Slovakia: Komárno, pp. 352361.

Horváth, Gy. (2004): Pedagógiai pszichológia. Nemzeti Tankönyvkiadó, Hungary, Budapest.

Jász K., Szarvák T. and Szoboszlai Zs. (2003): A szociális földprogram társadalomfejlesztési hatásai. In: Kállai E. (Ed.): A magyarországi cigány népesség helyzete a 21. század elején. Kutatási gyorsjelentések. MTA Etnikai-nemzeti Kisebbségkutató Intézet, Hungary: Budapest, pp. 139-145.

Karajz, S. (2021): The Impact of Digitalization on the Social Innovation of Peripheral Areas. In: Musinszki, Z., Horváthné Csolák, E., Szendi, D., Szücsné Markovics, K. (Eds.). The impacts of digitalization, social innovations and conflicts, University of Miskolc, Faculty of Economics, Hungary: Miskolc, pp. 63-75.

Keményné Pálffy, K. (2002): A szociális tanulás. In: B. Lakatos M. and Serfőző M. (Eds.) Pszichológia szöveggyüjtemény óvodapedagógus hallgatóknak, Trezor Kiadó, Hungary: Budapest.

Kocziszky Gy.,Veresné Somosi M. and Balaton K. (2017): A társadalmi innováció vizsgálatának tapasztalatai és fejlesztési lehetősége, Vezetéstudomány, vol. 48 (6-7), pp. 1519.

Kozma Tamás (1999): Bevezetés a nevelésszociológiába. Nemzeti Tankönyvkiadó, Hungary: Budapest. 
Kozma, T., Teperics, K., Erdei, G. and Tőzsér, Z. (2011): A társadalmi tanulás mérése - egy határokon átnyúló térség (Bihar - Bihor Eurorégió) esete, Magyar Pedagógia, vol. 111 (3), pp. 189-206.

Kulcsár, L. (2017): A vidékfejlesztés elméleti megközelítése: regionális és kulturális összefüggések, Pro Ruris Egyesület, Hungary, Mezőmadaras.

Musinszki, Z. (2019): A mezögazdasági tevékenység költség-és teljesítménykontrollja, Saldo, Hungary: Budapest.

Nemes, G. (2018): A társadalmi innováció és integrált vidékfejlesztés - két jó gyakorlat, Észak-magyarországi stratégiai füzetek, vol. 15 (3), pp. 69-78.

Nemes, G. and Varga, Á. (2017): Társadalmi innováció és társadalmi tanulás a vidékfejlesztésben, Mérleg és Kihívások IX. Nemzetközi Konferencia, Miskolc, Hungary, pp. 434-444.

Németh N. (2011): Helyi kezdeményezésü gazdaságfejlesztési programok vizsgálata, KTI könyvek 14., Hungary: Budapest.

Petrovicsné Takács R. (2006): A belecskai modell. In: Nagyné Varga I. and Landau E. (Eds.): Szociális földprogram modellek. Jász-Nagykun-Szolnok Megye Esély Szociális Közalapítvány Regionális Szellemi Forrásközpont, Hungary: Szolnok.

Reed, M. S., Evely, A. C., Cundill, G., Fazey, I., Glass, J., Laing, A., Newig, J., Parrish, B., Prell, C., Raymond, C., Stringer, L. C. (2010): What is social learning?, Ecology and Society, $\quad$ vol. $15 \quad$ (4) [Online]; Available: https://www.ecologyandsociety.org/vol15/iss4/resp1/

Solymosi, K. (2004): Fejlődés és szocializáció. In: N. Kollár K. and Szabó É. (Eds.) Pszichológia pedagógusoknak, Osiris Kiadó, Hungary: Budapest.

Szucsne Markovics, K. (2015): A társadalmi vállalkozások finanszírozási lehetőségei; In: Ferencz Á. (Ed.): II. Gazdálkodás és Menedzsment Tudományos Konferencia: "A vidék él és élni akar"; Kecskemét, Hungary: Kecskeméti Főiskola Kertészeti Főiskolai Kar, pp. 676680.

Szucsne Markovics, K. (2021): Advantages and Disadvantages of Getting Involved in Social Innovation Processes for For-profit Companies from the Perspective of Company Directors; In: Musinszki, Z., Horváthné Csolák, E., Szendi, D., Szücsné Markovics, K. (Eds.): The impacts of digitalization, social innovations and conflicts, University of Miskolc, Faculty of Economics, Hungary: Miskolc, pp. 5-25.

Urbán, R. (2007): Szociális-kognitív tanuláselméletek. In: Gy. Kiss E. and Oláh A. (Eds.) Vázlatok a személyiségről, Új Mandátum Könyvkiadó, Hungary: Budapest.

Vercseg, I. (2013): Társadalmi tanulás - közösségi tanulás, Parola, vol. 4.

Veresné Somosi, M. and Balaton, K. (2020): A társadalmi innováció fogalma. In: Smuk, P. (Ed.) Társadalmi fenntarthatóság, Ludovika Egyetemi Kiadó, Hungary: Budapest, pp. 1936. 


\section{International Conference on New Trends in \\ Management, Business and Economics}

\section{5-27 June 2021 - Vienna, Austria}

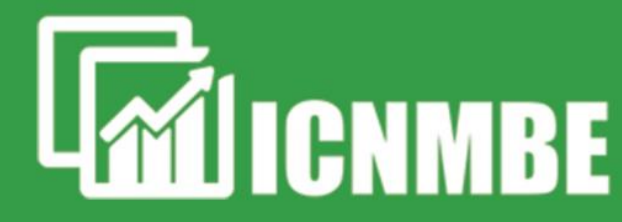

Veresné Somosi, M. and Varga, K. (2021): Conceptualisation as a tool in understanding social innovation - methods, case studies, practices. University of Miskolc, Hungary: Miskolc.

Vincze, M. (2013): A vidékfejlesztés problémáinak rendszerszemléletü megközelítése. Romániai sajátosságok, Erdélyi Múzeum, vol. 75 (3), pp. 30-51. 